Ryszard Wilczyński*

\title{
Global Imbalances: The Evolution of the Process and Policy Responses
}

\section{Abstract}

During the last ten years the global economy recorded strong growth with only mild and short slowdown at the early 2000's and with the another slowdown in 2007-2008. This growth was driven by the high dynamics of global demand, in excess of production capacities, and led to increasing tensions and disequilibrium such as asset bubbles, external imbalances and, ultimately, inflationary pressures and a turbulence on financial markets in 2007-2008.

There are disagreements among economists and policy makers about the causes and implications of global imbalances. A "sustainability view" maintains that global financial markets provide a useful framework for a relatively smooth unwinding of global imbalances. A "critical view" emphasizes an overshooting by financial markets and the need for policy responses to global imbalances. The article argues in favor of the latter view and maintains that it is important to consider these imbalances linked to other market failure - related risks to a sustainable growth of the global economy. Policy adjustments to global imbalances should be internationally coordinated. The effectiveness of policy responses to global imbalances will be enhanced if action is organized within the framework of a credible global financial institution.

\section{Introduction}

The term global imbalances is usually used to reflect an unbalanced current account position of countries (global current account imbalances). Conceptually, current account imbalances imply referring to an equilibrium, or optimal, current account which is

\footnotetext{
* Prof. dr hab., Wyższa Szkoła Finansów i Zarządzania w Warszawie.
} 
determined by fundamentals of the economy relative to other economies. These fundamentals include such factors as productivity differentials, factor endowments, demographics and age structure, terms of trade, world interest rates. ${ }^{1}$

Such an equilibrium current account provides a benchmark against which the evolution of the actual current account can be assessed. For example, if the latter deficit exceeds the optimal current account deficit there is an indication towards excessive deficits, or towards imbalances, with negative effects for the economies. There are several aspects of such imbalances:

- the nature of the causes of imbalances: temporary or structural; market- or policy driven; originating from a given country or from its partners;

- the size of imbalances: it affects their effects;

- the time horizon of the adjustments needed: current or future adjustments.

Imbalances caused by temporary factors, such as cyclical factors or occasional shocks (e.g. of terms of trade) are expected to unwind in an orderly way over time and therefore are not relevant for the judgment of the current account whereas structural causes (e.g. permanent misalignment in exchange rate policies) are critical here. ${ }^{2}$

A current account position results basically from changes in prices and quantities which follow the actions and preferences of market participants. As the market mechanism ultimately leads towards an equilibrium it may also, however, lead to an overshooting, a situation which requires an abrupt and strong correction of prices or quantities. In other cases, a current account imbalance may result from the misguided macroeconomic policies. Addressing imbalances, whether market or policy driven, may require policy responses.

Current account imbalances are considered as significant if addressing them involves disruptive adjustments (e.g. sizeable shifts in exchange rates). An assessment of the significance of misalignments and of imbalances involves, however, a judgmental component. It is a forward looking assessment of risks of disruptive adjustments over time; they do not necessarily occur now.

In parallel to current account developments the need for adjustments may derive also from abrupt reversals in external capital flows. It is therefore necessary to consider current account balance in relationship with the external asset position of a country. This relationship is included in the following equation (Lane, Milesi-Ferretti, 2006):

where:

$$
\mathrm{B}(\mathrm{t})-\mathrm{B}(\mathrm{t}-1)=\mathrm{CA}(\mathrm{t})+\mathrm{KG}(\mathrm{t})+\mathrm{E}(\mathrm{t}),
$$

$\mathrm{B}(\mathrm{t})-\mathrm{B}(\mathrm{t}-1)$ is a change in the net external asset position,

${ }^{1}$ The equilibrium current account balance can be derived from the notion of an intertemporal solvency (as consistent with the assumption that all external debt will be ultimately repaid); of current account sustainability (which adds to the notion of solvency the idea of constant policies over time); or of optimal consumption - smoothing current account (as consistent with the utility maximization of consumption over time). J. Ostry, Current Account Imbalances in ASEAN Countries: Are They a Problem? Working Paper No 51, IMF 1997, pp. 4-7.

${ }^{2}$ Structural nature of current account imbalances show similarity to the concept of structural fiscal balance. 
$\mathrm{CA}(\mathrm{t})$ is a current account balance,

$\mathrm{KG}(\mathrm{t})$ is a change in stocks of net foreign assets minus the underlying flows, $\mathrm{E}(\mathrm{t})$ is a factor including capital account transfers and errors and omissions.

An equilibrium current account leads towards the net external asset position to change in a way consistent with the economy fundamentals vis a vis other economies. The current account surplus and the corresponding increase in stocks of the net foreign assets contributes to the improvement of the net external position. The economies with current account deficits are borrowing internationally and their net external asset positions go down. The relationship between the current account and the net external financial position may be, however, more complex due to e.g. valuation changes of assets and liabilities which are not reflected in the current account.

It is reasonable to extend an approach to external imbalances beyond the positions of individual countries taken in isolation, to an international perspective which recognizes an increasing financial globalization and a larger degree of exposure of a country to developments on external financial markets. During the last ten years the US have been running large current account deficits whereas big parts of Asia and the Middle East recorded even larger surpluses.

Global implications of these imbalances are discussed in this article. The rest of the article is organized as follows: in section one the main stylized facts on global imbalances are presented; in section two the driving forces and effects of global; imbalances are described and assessed; section three elaborates on policy responses to global imbalances, in particular on international policy actions; the final section concludes.

\section{Some stylized facts}

Table 1 below includes data illustrating current account imbalances of major economies and country groups during the last decade. It highlights the main trends in global imbalances in that period. The dominating pattern shows a substantial deterioration in the US current account balance and, as a counterpart, growing current account surpluses in other major economies or regions. The largest surpluses have been recorded in Asia,

Table 1. Current account imbalance as percent of GDP, 1998-2007

\begin{tabular}{|l|c|c|c|c|c|c|c|c|c|c|}
\hline & $\mathbf{1 9 9 8}$ & $\mathbf{1 9 9 9}$ & $\mathbf{2 0 0 0}$ & $\mathbf{2 0 0 1}$ & $\mathbf{2 0 0 2}$ & $\mathbf{2 0 0 3}$ & $\mathbf{2 0 0 4}$ & $\mathbf{2 0 0 5}$ & $\mathbf{2 0 0 6}$ & $\mathbf{2 0 0 7}$ \\
\hline US & $-2,3$ & $-3,1$ & $-4,2$ & $-3,9$ & $-4,6$ & $-4,8$ & $-5,5$ & $-6,1$ & $-6,2$ & $-5,9$ \\
\hline China & 3,3 & 1,6 & 1,9 & 1,5 & 2,8 & 2,8 & 3,6 & 7,2 & 9,5 & 11,1 \\
\hline Japan & 3,0 & 2,6 & 2,5 & 2,1 & 2,8 & 3,2 & 3,7 & 3,6 & 3,9 & 4,9 \\
\hline Eurozone & 0,9 & 0,4 & $-0,5$ & 0,2 & 1,2 & 0,5 & 1,1 & 0,2 & 0,0 & $-0,2$ \\
\hline Developing Asia & 2,6 & 2,4 & 2,1 & 1,7 & 2,8 & 2,7 & 2,6 & 4,0 & 5,9 & 6,7 \\
\hline Middle East & $-4,9$ & 2,0 & 11,0 & 5,9 & 4,6 & 8,3 & 11,8 & 19,7 & 20,9 & 19,8 \\
\hline Russia & $-0,8$ & 11,3 & 17,2 & 10,9 & 8,9 & 8,2 & 10,1 & 11,0 & 9,5 & 5,9 \\
\hline
\end{tabular}

Source: World Economic Outlook Database April 2004, 2008 IMF 2004, 2008. 
particularly in China and Japan, in the Middle East and in other major oil exporting countries.

In the early 1990's the US current account deficit was quite moderate, in the range of $1-2 \%$ of GDP. It is since 1997 when the deficit has been increasing to unprecedented levels, reaching $6,2 \%$ in 2006 . The process was driven by the deterioration of the trade balance. 2007 saw some improvement of the US current account balance to $-5,9 \%$ of GDP.

A substantial deficit of 3,5\% of GDP emerged in the US current account also in the early 1980's. At that time the US deficit was mirrored, to a dominating extent, by current account surpluses in just two countries: Japan and Germany. The adjustment of exchange rates (a depreciation of the US dollar against currencies of the surplus countries, known as the Plaza agreement of 1985) helped to unwind current account imbalances two decades ago; around 1990 the US deficit declined to about 1\% of GDP.

During the last decade, however, the pattern of current account imbalances has been more complex. In 2007 the US current account deficit, which accounted to 1,36\% of the world GDP, had numerous and different counterparts. Among surplus economies are: China $(0,63 \%$ of world GDP), Japan $(0,42 \%)$, Middle East $(0,5 \%)$, four Asian new industrialized countries plus Indonesia, Malaysia and Thailand $(0,3 \%)$, Russia $(0,15 \%) .^{3}$ Any action addressing imbalances would therefore be this time more difficult.

The evolution of the net external asset position in the last decade confirms, in principle, the following pattern: current account deficit countries see deterioration while current account surplus countries see an improvement of their net external asset positions. Deficit countries have to borrow externally and that adds to their net external liabilities. The US net external liabilities rose from less than 3\% of GDP in 1990 to over $20 \%$ in 2000 - 2004 (Ahearne, von Hagen, 2005). However, despite the fact that during the 2000's US current account deficits have been continuously large and mainly increasing, after 2002 its net external position, as scaled to world GDP, remained broadly stable with even some signs of improvement, due to return differentials in favor of US assets. These assets are denominated in foreign currencies and are largely in the form of equity and foreign direct investment whereas US liabilities are mostly debt instruments and are denominated in the domestic currency. The gradual depreciation of the dollar which speeded up after 2002 as well as improving investment opportunities have increased the dollar rate of return on US external assets relative to liabilities and therefore helped to improve the US net external asset position.

On the other side, regions with current account surpluses have been showing improvements in their net external asset positions. Largest improvements have been

Table 2. US net external asset position as percent of world GDP, 1999-2007

\begin{tabular}{|c|c|c|c|c|c|c|c|c|}
\hline 1999 & $\mathbf{2 0 0 0}$ & $\mathbf{2 0 0 1}$ & $\mathbf{2 0 0 2}$ & $\mathbf{2 0 0 3}$ & $\mathbf{2 0 0 4}$ & $\mathbf{2 0 0 5}$ & $\mathbf{2 0 0 6}$ & $\mathbf{2 0 0 7}$ \\
\hline$-1,3$ & $-2,2$ & $-3,1$ & $-3,4$ & $-3,1$ & $-3,1$ & $-2,9$ & $-3,0$ & $-2,5$ \\
\hline
\end{tabular}

Source: H. Faruqee, IMF Sees Global Imbalances Narrowing, But More To Be Done, IMF Survey Magazine, February 19, 2008, p. 3.

\footnotetext{
${ }^{3}$ Own calculations based on World Economic Outlook Database April 2008...op.cit.
} 
experienced by the Middle East (with oil prices increasing) and emerging Asia (with expansion of exports). In particular, between the mid 1990's and mid 2000's external positions have been strengthened in Hongkong, China, Singapore, Taiwan, Malaysia: in Kuwait, Libya, Saudi Arabia, Yemen and Algeria; in Nigeria and Venezuela (Lane, MilesiFerretti, 2005).

One of the manifestations of global imbalances is the fast accumulation of huge foreign exchange reserves by central banks in current account surplus economies. Over seven years to March 2008 global foreign currency reserves increased by 4,9 trillion dollars, i.e. $70 \%$ of their value in the mid 2008. This trend is particularly strong in Asia. Among the largest ten foreign exchange reserve holding countries seven are from Asia, with China and Japan at the top of the list with the value of reserves of , respectively, 1,8 trillion and 1 trillion dollars in 2008 (Wolf, 2008). Top reserve - accumulating central banks have been increasing their shares in the total reserve accumulation. This suggests that the official financing of the US current account deficits becomes increasingly concentrated on fewer, mainly Asian, central banks. The speed of the accumulation of foreign exchange reserves is also remarkable in Russia and in the Middle East.

A part of the pools of national foreign exchange reserve assets is being channeled to sovereign wealth funds (SWF). ${ }^{4}$ Last decade has witnessed a very strong expansion of SWF in international markets. SWF have multiplied the value of the stock of their financial assets to an estimated 2,3 trillion dollars in 2007 and the total of their pools is growing rapidly. SWF originate, to a dominating extent, from current account surplus economies, mainly from Asia and the Middle East. ${ }^{5}$

Among the major objectives of SWF are improving return on foreign exchange reserves (or on commodity revenue) as well as, by diversifying assets, shielding the domestic economy from price fluctuations in international markets. ${ }^{6}$ It is worth emphasizing that these funds invest most in foreign assets while the strategy of SWF is less risk averse as compared to the management of foreign exchange reserves by central banks.

The last decade saw the large current account deficits and external liabilities in the US, mirrored by large current account surpluses, improving net external asset positions and an accumulation of foreign exchange reserves in emerging economies and Japan. These surpluses were being transferred to the US to finance its deficit. Although the process was so far relatively smooth, its sustainability remains the issue of extensive international debates.

${ }^{4}$ Sovereign wealth funds may also be funded by the sale of scarce resources (like oil) or from general tax revenues.

${ }^{5}$ Among five largest SWF having total assets close to 2 trillion dollars three are from Middle East (from United Arab Emirates, Saudi Arabia and Kuwait) and two are from Asia (from Singapore and China). A. Blundel-Wignall, Yu-Wei Hu, J. Yermo, Sovereign Wealth and Pension Fund Issues Financial Market Trends, OECD 2008, p. 6.

${ }^{6} \mathrm{SWF}$ have also developmental objectives, such as providing for pensions in the future or promoting industrialization. 


\section{Causes, effects and their assessments}

It is useful to discuss the anatomy and evolution of global imbalances against the shifts in world growth dynamics and patterns which were occurring during the last decade.

The dynamics of global growth has been increasingly dominated by robust growth of emerging and developing economies. In particular, within 2003-2007 these economies together accounted for around two - thirds of global growth and they account now for one third of global trade as well as for around a half of world GDP in ppp terms. Strong growth in emerging economies is being fueled by such structural factors as significant productivity gains due to technological catching up; internal migrations from the countryside into cities and by foreign direct investments. On the other side, in the US, and to some extent in several other large advanced economies, these structural growth factors - due to lower productivity gains, ageing population and offshoring capital - have been weaker than in emerging markets.

At first glance, such developments in growth dynamics should rather lead towards current account deficits in emerging world (robust growth) and surpluses in the US (weaker growth). High growth economies attract foreign capital leading to surpluses on capital accounts and to current accounts deficits as counterparts. Positive perspectives on high growth countries stimulate current consumption and imports. There are, however, policy-related factors working in the reverse direction. First, the US growth has been substantially strengthened by an expansionary macroeconomic policy. An expansionary monetary policy led to the accumulation and to the rise of prices of wealth assets in the form of equities (during 1996 - 2000) and of real estate (during 2002-2006) as well as it stimulated household indebtedness and, consequently, domestic demand. Demand has also been fueled by fiscal deficits during the first half of 2000's. Second, strong growth in emerging economies is attributed to an export driven strategy and to the rise in world commodity prices, i.e. to foreign rather than domestic demand. Contrary to the US, these economies have high saving rates. Different balances between domestic savings and investment demand produce current account deficits in the US and surpluses in emerging countries. These deficits and surpluses are interlinked as globally national deficits and surpluses have to balance out so that deficit economies can raise external funds to the extent provided by surplus economies.

In the existing research on the causes of global imbalances different studies recognize different driving factors of the process. ${ }^{7}$ The overview of those factors will be useful for assessing effects of and policy responses to global imbalances.

i) A Bretton Woods II concept which is composed of several, crucial elements (Dooley, Folkerts-Landau, Garber, 2003):

- the US economy is an engine of global growth and provides a huge export market for the rest of the world;

${ }^{7}$ Different approaches were also discussed and summarized by Polish authors: K. Lutkowski Problem międzynarodowej nierównowagi płatniczej, „Ekonomista” No 4/2006; K. Rybiński Globalne nierównowagi „Ekonomista” No 4/2006; M. Rubaszek Nierównowaga globalna: przyczyny oraz możliwe rozwiqzania, „Bank i Kredyt” No 7/2006. In this article we refer to main authors who represent different approaches to global imbalances. 
- US fiscal deficit is needed not only to fuel demand but also to finance international security for which the primary responsibility falls with the US;

- Asian countries play the role of "a periphery", the same as Europe and Japan played under original Bretton Woods system; these countries need to absorb huge labor surpluses, particularly from the rural areas, and to achieve strong growth of output and employment; Asian countries, with their unsophisticated financial systems which are unable to efficiently channel large domestic savings, pursue an export led strategy;

- Asian economies use their current account surpluses to finance large US consumption and investments.

Bretton Woods II view recognizes that such a system is coherent and therefore sustainable. It provides for a relatively stable prices, interest and exchange rates whereas major players benefit and maintain the system. The main driving force of imbalances is located in Asia rather than in the US.

ii) Another view recognizes the US economy as a source of global imbalances: ${ }^{8}$

- it is fiscal deficit which is producing current account deficit in the US ("the twin deficits" concept);

- a regime of global fixed exchange rates among major economies is reasonable;

- the US "contribution" to global imbalances comes also from insufficient private savings, asset price inflation and an expansionary monetary policy.

According to that view the likely adjustment is focused on the US side. It should be pursued via increase in US savings, including fiscal savings, whereas a necessary real appreciation in fast growing Asian economies should be achieved via domestic inflation rather than via nominal appreciation.

iii) The "savings glut" view believes that the major source of global imbalances is exogenous to the US; it is in emerging economies (Bernanke, 2005; 2007):

- domestic factors do not account for the deterioration of the US external balance;

- growth of incomes resulting from productivity increases (e.g. in China) or from high oil prices (in Middle East) contributes to the rise in savings for precautionary reasons, particularly when domestic financial systems and social safety nets are undeveloped;

- financial crisis of 1997 and underdeveloped financial institutions led to declines in investments in emerging Asia ("investment drought");

- fiscal consolidation in emerging economies also restrained the increase of their domestic demand.

The combined effect of these developments is a big rise in net savings and in current account surpluses in emerging economies. As globally the sum of national current account

${ }^{8}$ The analysis of global imbalances by R. McKinnon is focused on the US fiscal deficit and on exchange rates of major currencies. See his The World Dollar Standard and Globalization: New Rules for the Game Stanford University 2003; Why China Should Keep Its Exchange Rate Pegged to the Dollar. A Historical Perspective From Japan Stanford University 2006. The role of fiscal balance in the context of current account deficit was also discussed by M. Obstfeld and K. Rogoff The Unsustainable US Current Account Position Revisited Working Paper No 10869, NBER 2004. 
balances must be zero, the US, and to a certain extent some other industrialized countries, have to record current account deficit.

iv) "Globalization and technology" approach emphasizes the role of financial globalization and of productivity shocks (Cooper, 2005; Caballero, Farhi, Gourinchas, 2006). This approach extends the search for driving forces of global imbalances beyond trade and current account dimensions, to capital account and asset markets in which exchange rates are increasingly determined:

- capital flows dominate on international markets; they do not accommodate to trade flows any more but become autonomous;

- advanced financial globalization has reduced home bias in allocation of capital as well as - via synergy effects - it has increased global supply of capital;

- an increased and easier access to capital weakens macroeconomic discipline and delays an adjustment of imbalances;

- US non-residents are willing to invest into US dollar assets due to revolution in technology information and communication and related jump in productivity; due to sophisticated financial system as well as due to low geopolitical risk of the US.

Financial globalization helped to materialize the advantages of the US economy which attract external capital to that country. Huge capital inflows manifest a confidence to the US which outperforms Eurozone and Japan in terms of growth and emerging markets in terms of financial assets. Such inflows automatically result in American current account deficits.

v) Another view is focused on the accumulation of foreign exchange reserves in emerging countries (Aizenman, Lee, 2005):

- in 1997 speculative attacks on Asian currencies were sensitive to the level of reserves;

- foreign exchange reserves provide an insurance against currency crisis in view of volatile international capital flows and they weaken a dependence of the country on international institutions like the IMF;

- accumulation of reserves was also pronounced in oil exporting countries.

Huge reserves in emerging world provide a pool from which US expenditures are being financed and that results in deficits on US current account.

vi) Several economists investigate the role of exchange rate levels and policies in the evolution of global imbalances. They focus on misalignments of exchange rates of major currencies, in particular on an overvaluation of the dollar and an undervaluation of Asian currencies. Sometimes they combine the responsibility for global imbalances between misaligned exchange rate levels and US fiscal deficits and also include an unbalanced saving and demand patterns across the globe. They indicate the risk of abrupt adjustments and see the need for joint policy actions. ${ }^{9}$

9 The role of exchange rates is thoroughly discussed by economists associated with the Peterson Institute for International Economics in Washigton DC. (e.g. J. Williamson, W. Cline) and with the Breugel Institute in Brussels (e.g. J. Pisani-Ferry, A. Ahearne). See also M. Obstfeld, K. Rogoff The Unsustainable US Current Account Position Revisited Working Paper No 108691, NBER 2004. For a more combined approach to causes of global imbalances see N. Roubini, B. Setser The US as a Net Debtor: The Sustainability of the US External Imbalances NY University 2004. 
The assessment of global imbalances and of its effects predominantly boils down to the issue of sustainability/unsustainability of imbalances and of orderly/disruptive adjustments.

Under sustainability approach, Bretton Woods II, savings glut, globalization and technology or reserve accumulation views suggest that the pattern of international payments with global imbalances is sustainable; adjustments, if needed, will take years, will be gradual and will occur in an orderly manner.

East Asia and Middle East have excess savings and are happy to accumulate dollars and channel them to dollar denominated assets in order to resist appreciation of their currencies and to stimulate their exports, output and employment growth. These excess savings require current account deficits elsewhere, particularly in the US economy which attracts resources due to the greater effectiveness of associated financial assets, due to a productivity shock, sophistication of the US financial sector and lower geopolitical risk. After buying US debt instruments Asian countries pull back a portion of their savings as foreign direct investments. As long as excess savings outside the US exist and foreigners are willing to purchase American assets, the US current account deficit can be sustained. Under such system both major participants achieve benefits (high consumption and investment in the US; strong economic growth in Asia), despite some costs which, however, they accept (for the US it is an increased competition from Asian imports to domestic producers; for Asia it is a cheap credit to the US in the form of huge dollar reserves). Shifts of exchange rates provide an usual instrument of an orderly adjustment under such system.

It is claimed, that in the context of technology development and of globalization, US current account deficit is not only sustainable but also it is a natural feature of the global economy. In particular, globalization-related positive supply shocks have helped make the US the main supplier of competitive financial assets whereas emerging countries show an increasing demand for theses assets. It is, therefore, natural that their savings are invested in the US. Under this "new paradigm" such trend is structural and may be continued for a long time (Xafa, 2007). It is also claimed that global imbalances can help support anti-cyclical policy as they can weaken tendencies towards recession (trade surpluses are equivalent to an increased demand for domestic goods) or to overheating (trade deficits, i.e. import surpluses, bring supply closer to demand in a domestic market (Cooper,2005; Bernanke, 2007). The US technological and human capital advantage will in the long run help maintain solid growth and the strength of dollar which, now and in the foreseen future, remains the main international and reserve currency.

Foreign exchange reserves pooled to sovereign wealth funds play a useful, stabilizing role in the global economy. In response to the financial crisis in the US, those funds invested, since the beginning of 2007, more than 60 billion dollars in Western financial institutions. ${ }^{10}$

${ }^{10}$ E.g. Government of Singapore Investment Corporation injected 7,9 billion dollars in UBS; Temasek injected 9,2 billion in Standard Chartered and 4,4 billion in Merrill Lynch; China Investment Corporation injected 5 billion in Morgan Stanley. J.O'Neill, E. Nielsen In Defence of Sovereign Wealth Funds Global Economic Paper No 167, Goldman Sachs, London 2005, p.6. 
To support the case for sustainability of global imbalances, an improving trend of the US net external asset position is recalled. The negative position declined from almost $25 \%$ of GDP in 2002 to $19 \%$ in 2007 and nowadays is not putting an exceptional burden on the US economy. Since 2007 US current account deficit is also slightly declining, due to a slowdown in GDP growth a swell as to gradually weaker dollar. Further weakening of growth in 2008 will likely reinforce this trend.

Those who advocate the sustainability of an international payments system with global imbalances, emphasize that despite national imbalances global equilibrium has been so tar reproduced in a relatively smooth process which can be continued also in the future. Cyclical forces will drive US current account deficit slowly down, perhaps with some gradual dollar depreciation, if there are no major shocks and global monetary policy is run adequately, in particular if asset price inflation is controlled. Other factors, which help orderly unwind global imbalances, include: the fact that US is borrowing in its own currency; floating dollar and likely cautious response by huge dollar reserve holders.

The critical view is focused on risks associated with global imbalances. Developments in external imbalances, which occurred in the last decade, cannot be continued without limits. Unless policy measures designed to mitigate these developments are implemented, global imbalances will be unwound in an abrupt manner, with disruptive effects to international prices and with international recessionary impacts.

The advocates of the critical view on global imbalances (including R. McKinnon, M. Obstfeld, K. Rogoff, B. Eichengreen, N. Roubini, B. Setser) indicate flaws among arguments in favor of sustainability view as well as provide their own arguments suggesting unsustainability of the current trajectory of global imbalances.

The flaw of the concept of the self-perpetuating Bretton Woods II system is that one of its main components - Asia as a new periphery - is not a cohesive bloc of economies which would act in their collective interest. There are many differences among Asian countries which make difficult their common international role as large reserve holders and providers of financing of US debt. Strengthening an international security by the US may not be a temporary issue, associated with the increase in fiscal expenditures but a long term one which requires tax rates reduction, resulting in a permanent increase of the US domestic demand on the one hand and further increase in reserves of emerging countries, to levels associated with risks, on the other. Finally, critics of Bretton Woods II concept indicate that the US may not be politically comfortable being permanently and increasingly financed by its big competitor, i.e. China.

The savings glut concept turns the responsibility for global imbalances completely away from the US. The case that the US current account deficit is willingly financed externally due to high and safe returns in the US is also rising doubts as it is Asian central banks, not private investors, which predominantly channel capital to the US. In any case, the willingness of foreign investors to hold US assets in their portfolios is not unlimited. Furthermore, the excess savings in Asia may be temporary, due to a decline of investment after the financial crisis in that region and not permanent which would imply structural abundance of capital in emerging markets.

A focus on the accumulation of foreign reserves in Asia and Middle East as the main driver of global imbalances is also criticized on a following account: reserves are 
excessive, with levels far beyond requirements of insurance against volatile capital flows. Several benchmarks of reserve prudence (such as total external debt maturing within one year or three months' import coverage or broad money) are exceeded in case of Asia. That indicates mercantilist motives of reserve accumulation, associated with keeping exchange rates undervalued as a part of an export-led growth.

As reserves which are already high continue to grow, questions on their limits and efficiency arise. The majority of Asian reserves is held in US Treasury bills which provide lower yields than rates of return paid to foreign investors in Asia. Sterilization of foreign reserves entails fiscal costs. If not sterilized, reserves spill over into monetary creation and increase inflationary pressures.

Piling up foreign reserves in Asia imply growing of US external debt. In these circumstances, the shift by emerging countries not to increase further their dollar reserves cannot be excluded. Such circumstances can activate the process of substantial decline of the dollar, rise in US interest rates and sliding into recession.

Channeling part of reserves into sovereign wealth funds raises some concerns about governance, investment objectives, asset allocation and political interference. Whereas central banks, directly or indirectly, have responsibility for stability of international financial system, sovereign wealth funds primarily maximize value of their portfolios.

Some authors express concerns related to exchange rate levels and policies. E.g. Obstfeld and Rogoff (2004) warned, increasingly over time, against collapse of the US dollar due to global imbalances; at the beginning of 2000's they estimated that adjustment of global imbalances would require c.a. $15 \%$ decline of the dollar real exchange rate whereas in the mid 2000's - 20-40\% decline. Economists associated with the Peterson Institute of International Economics maintain that without appreciation of Asian currencies, which would comply with fundamentals, unwinding of global imbalances may be disruptive. A continuation of current trends in global imbalances would further increase US foreign liabilities to the levels of c.a. $50 \%$ of GDP by 2011, which may undermine the willingness of foreign investors to finance US current account deficit (Ahearne et all. 2007). Another effect would be the accumulation of foreign exchange reserves in Asia to implausible levels. Policy adjustments should be initiated; otherwise, in case of marketled adjustment, reduced foreign financing of US deficits, if it is the case, could lead to a sharp fall of the dollar, negative wealth effect and economic slowdown in the US and elsewhere. Persistent undervaluation of Asian currencies may also lead to protectionist pressure sin the US as well as in Europe which - due to the floating regime of the euro is also affected.

M. Wolf (2008) maintains that huge foreign reserves of emerging economies targeting US dollar assets imply US trade deficits. But trade deficit is contractionary. In order to offset this effect domestic demand had to be stimulated: in case of the US it was predominantly household demand through increased indebtedness resulting in a credit crunch. Another effect of the expansion of demand, also that of fast growing economies, is a substantial increase of commodity prices. It is, therefore, a link between global imbalances, disruptions in the US financial market and an increase in global inflation, with the sources of the process located outside rather than within the US economy. There are, however, also arguments maintaining that it is insufficient savings in the US which 
is among major driving forces of global imbalances (Mc Kinnon, 2006; Roubini, Setser, 2004).

\section{Policy responses. The position of the International Monetary Fund}

The need for policy actions is rooted in the view that there are limits to the developments of global imbalances. Turbulence in financial markets, which occurred in 2007-2008, should result in some adjustment of global imbalances, through a slowdown of demand in the US, regardless of policy. This is, however, at substantial cost of fragility of financial markets and of strongly subdued growth in the US (down to 1\% in 2008) and, to a lesser extent, in the rest of the world.

It may be claimed that it is not an usual cyclical adjustment under which the US current account deficit will be gradually driven down but a more durable crisis which may encourage countries to recover from weak growth through e.g. protectionist measures.

AS global imbalances affect - more or less directly - many countries, policy actions should involve an international coordination. Globalization brings numerous externalities between countries: policies implemented in one country has an influence has an influence on economic situation in other countries. Monetary and exchange rate policies in Asia are fuelling, via effects on international liquidity, demand and current account deficit in the US. In emerging economies, accumulation of reserves channeled to the US restrains depreciation of the dollar and maintains US trade deficit. Policies in Asia to drive savings upwards also result ultimately in global imbalances. Due to such externalities there is an increased need for collective responses.

The International Monetary Fund (IMF) is the most appropriate platform for working out and implementation of collective actions designed to solve global imbalances. First, the IMF is mandated to care about the stability of the international financial system, including the stability of exchange rates and balancing external positions of its members. Second, the IMF is a major multilateral international financial institution with the membership of 185 countries.

The position of the IMF on global imbalances includes three components; diagnosis of global imbalances; recommendations to solve imbalances and actions and procedures designed to implement these recommendations.

The IMF diagnosis of global imbalances is based on the evolution of savings and investment patterns across major economies. Through the last decade, global savings and investment, as percent of GDP, have been falling. The fall in global saving is attributed to developments in industrial countries (where household saving fell due to easily available credits and due to rising asset prices; public saving fell due to increased expenditures and restrained taxes), while saving in emerging economies increased (private saving increased due to strong output growth; public saving increased particularly in China and Middle East). Investment rates were falling to unusually low levels across the globe, both in industrial and in emerging economies (except China). Several Asian economies are "underinvesting". This constellation of saving and investment produced 
current account imbalances which have been increasing to unusually levels in the mid 2000 's and were slightly declining thereafter. Low investment rates resulted in excess savings and in low level of long term real interest rates (World Economic Outlook, 2005).

The IMF diagnosis of global imbalances is centered around global saving and investment patterns but it also provides a comprehensive background and analysis of factors significant for saving and investment behavior. Consequently, it has common points, more or less direct, with other views on an cause of global imbalances.

The IMF recommendations designed to solve global imbalances depart from three important points:

- they assume that there is a risk of disruptive adjustments and therefore a need for policy actions;

- they emphasize that current global imbalances involve large and diverse group of countries (in contrast to the mid 1980's where Japan and Germany were the only two dominating counterparts to current account deficits of the US); therefore many countries should participate in policy adjustments and their actions should be coordinated;

- they emphasize that an orderly unwinding of global imbalances should be done in a manner which is also supportive for global economic growth.

The IMF does not exclude an orderly adjustment of global imbalances led by the market mechanism. It is likely that over time private savings in the US gradually rise as housing market weakens whereas in Asia domestic investment and consumption go up as well as real exchange rates driven by higher inflation. 2007 and 2008 witness indeed some narrowing of global imbalances, with the US current account deficit declining to about $5,5 \%$ of GDP and with the net foreign asset position remaining stable. The decline of current account deficit reflects partly a gradual weakening of the dollar but also a slowdown of US growth attributed to the turbulence in financial markets. Strongly subdued US growth and fragility of financial markets, also outside the US, are signs of an abrupt, or at least excessive, adjustment. It may be claimed that instead for waiting for such market-led adjustments, which imply overshooting, it may be reasonable to correct global imbalances in advance with policy measures.

The IMF emphasizes that despite recent narrowing of global imbalances, associated risks still remain. The turmoil on the US financial market may undermine confidence in the quality of US financial assets and willingness of foreign investors to finance US deficits. High and volatile oil prices may slow narrowing of global imbalances. Dollar depreciation has been asymmetric and in countries with noticeably more dollar depreciation (and more appreciation of their currencies) protectionist sentiments could be fueled. The Fund admits, without developing that aspect of global imbalances, that rising international financial integration may reduce these risks. ${ }^{11}$

It is remarkable that the IMF considers global imbalances in the context of other risks to sustainable economic growth, such as risks stemming from oil market, inflation,

${ }^{11}$ According to another and comprehensive view (Xafa, 2007) financial integration provides a framework under which global imbalances are orderly and naturally solved. 
financial conditions or from domestic demand in major economies. It is a useful approach as those risks are interlinked. E.g. adverse financial conditions, which are currently considered as the biggest downside risk to global growth, are being fueled by, among others, an expansionary US monetary policy which also contributed, via wealth effects, to stronger domestic demand and current account deficit. High oil prices are widening global imbalances as petrodollars recycled to the US support consumption and fuel the deficit on current account. Despite some decline in 2007-2008, global imbalances remain the second biggest downside risk to global growth (World Economic Outlook, 2008).

Policy actions recommended by the Fund are based on the idea of rebalancing global demand in current account deficit countries domestic demand growth (relative to domestic supply) should be slowed down whereas in current account surplus countries domestic demand should be strengthened. It is necessary to combine these actions with the realignment in exchange rates.

These general recommendations, taken as a package, have been addressed to individual countries responsible for development of global imbalances. The US was recommended to improve incentives for private savings and to gradually reduce general government fiscal deficit. China was recommended to improve the quality of financial intermediation in order to facilitate investments; to increase public social expenditures in order to lower precautionary savings and boost consumption; to allow greater currency appreciation. Oil exporters were suggested to boost domestic spending and allow exchange rates to reflect improved terms of trade. Japan and the euro are recommended to speed up reforms of labor and product markets in order to increase flexibility and foster competition with positive effects for demand and economic growth.

In search of better efficiency of policy actions, new procedure has been introduced by the IMF. Multilateral consultations are designed to solve the issues of systemic importance for the global economy and international financial system. The topic of the first round of multilateral consultations is global imbalances. Under the consultations, five participants: the US, euro area, Japan, China and Saudi Arabia have provided national plans aimed at reducing global imbalances. Those plans comply with the IMF policy recommendations package and provide detailed actions, already taken or anticipated, to support an orderly unwinding of global imbalances.

While major economies agreed that such policies are well designed and would help reduce imbalances, the implementation of policy measures remains critical. In principle, multilateral consultation is a voluntary procedure. While reducing global imbalances is a common objective, a participating party that moves first has not enough certainty that other parties would follow and it risks being worse off - a situation illustrating "a prisoner's dilemma" from the game theory (El Erian, 2008). The language of agreed policy steps includes some flexibility; e.g. China committed itself to improve its exchange regime "in a gradual and controllable manner" - gradual allows for various sizes of change as well as for various timings.

The main incentive for individual countries to implement steps agreed under multilateral consultations is reputation; if they do not implement the Fund would declare in its bilateral surveillance reports that a country breached agreements of consultations. 
This, however, may be not sufficient incentive when the legitimacy of the IMF is raising doubts.

\section{Conclusion}

The last decade has witnessed the increasing, to high levels, external imbalances of several major economies. In particular, the US has recorded large current account deficits whereas the economies of Asia and Middle East even larger current account surpluses.

An issue of the anatomy of the process of growing imbalances as well as its effects for global economy has been and still is controversial among academicians and policy makers. Main controversies regard the role of the market and of the macroeconomic policies in the process; the risks of global imbalances to sustainability of global growth; the size and nature of adjustments needed to unwind imbalances.

The article argues that in the context of the linkage of global imbalances to other tensions in a global economy, it is reasonable that policy makers proactively respond to growing imbalances. Due to externalities involved in the process, an international coordination of policy actions is needed. Multilateral consultations, the new procedure of the International Monetary Fund, provide a well designed action plan to deal with global imbalances. What matters now is an efficient implementation of this plan.

\section{References}

Ahearne A., von Hagen J., Global Current Account Imbalances: How to Manage the Risk for Europe?, Breugel Policy Brief, 2005 nr 2.

Ahearne A. et al., Global Imbalances: Time for Action, Peterson Institute Policy Brief, $2007 \mathrm{nr} 4$.

Aizenman J., Lee J., International Reserves: Precautionary vs Mercantilist Views; Theory and Evidence, IMF Working Paper 2005, nr 198.

Bernanke B., The Global Savings Glut and the US Current Account Deficit, US Federal Reserve 2005, Washigton D.C.

Bernanke B., Global Imbalances: Recent Developments and Prospects, Bundesbank Lecture, September 2007, Berlin.

Blundel-Wignal A., Yu-Wei Hu, Yermo J., Sovereign Wealth and Pension Fund Issues, Financial Market Trends, OECD 2008.

Caballero A., Farhi E., Gourinchas P., An Equilibrium Model of Global Imbalances and Low Interest Rates, NBER Working Paper 2006, nr 11996.

Cooper R.N., Living with Global Imbalances: A Contrarian View, Policy Briefs in International Economics 2005, $\mathrm{nr} 3$.

Dooley M., Folkerts-Landau D., Garber P., An Essay on the Revived Bretton Woods System, NBER Working Paper 2003, nr 9971.

El Erian M., How to Manage Global Imbalances, Financial Times, 16 June 2008.

Faruquee H., IMF Sees Global Imbalances Narrowing but More to be Done, IMF Survey Magazine, February 19, 2008.

Lane P., Milesi-Ferretti G., A Global Perspective on External Positions, IMF Working Paper 2005, nr 161.

Lane P., Milesi - Ferretti G., Capital Flows to Central and Eastern Europe, IMF Working Paper 2006, nr 188.

Lutkowski K., Problem międzynarodowej nierównowagi płatniczej, „Ekonomista”, 2006 nr 4. 
Mc Kinnon R., The World Dollar Standard and Globalization; New Rules for the Game, Stanfrod University 2003.

Mc Kinnon R., Why China Should Keep Its Exchange Rate Pegged to the Dollar. A Historical Perspective from Japan, Stanford University 2006.

Obstfeld M., Rogoff K., The Unsustainable US Current Account Position Revisited, NBER Working Paper 2004, nr 10869.

O’Neill J., Nielsen E., In Defence of Sovereign Wealth Funds, Global Economic Paper 2005, nr 167, Goldman Sachs, London.

Ostry J., Current account imbalances in ASEAN countries: are they a problem?, IMF Working Paper 1997, nr 51.

Roubini N., Setser B., The US as a Net Debtor. The Sustainability of the US External Imbalances, NY University 2004.

Rubaszek M., Nierównowaga globalna: przyczyny oraz możliwe rozwiqzania, „Bank i Kredyt”, 2006 nr 7.

Rybiński K., Globalne nierównowagi, „Ekonomista”, $2006 \mathrm{nr} 4$.

Wolf M., How Imbalances Led to Credit Crunch and Inflation, Financial Times 17 June 2008.

World Economic Outlook Database: April 2004, April 2008, IMF, Washington DC., 2004; 2008.

World Economic Outlook: September 2005, IMF, Washington DC., 2005, chapter II. Global Imbalances: A Saving and Investment Perspective.

Xafa M., Global Imbalances and Financial Stability, IMF Working Paper 2007, nr 111.

\section{Globalna nierównowaga płatnicza: jej zmiany oraz reakcje polityki makroekonomicznej}

\section{Streszczenie}

W trakcie ostatnich dziesięciu lat gospodarka światowa osiagnęła wysoka dynamikę, która uległa niewielkiemu i krótkotrwałemu obniżeniu na poczatku dekady lat 2000 oraz weszła w kolejna, prawdopodobnie o wiele większq, faze spowolnienia $w 2008$ r.

Szybki wzrost globalnej gospodarki nie byt pozbawiony napięć. Jednym z nich jest narastajaca międzynarodowa nierównowaga płatnicza. Na rachunku obrotów biezacych USA wystapity rekordowo wysokie deficyty, a w krajach Azji i Bliskiego Wschodu - nadwyżki.

Przyczyny i skutki globalnej nierównowagi płatniczej sq przedmiotem kontrowersji w kołach akademickich, jak $i$ wśród polityków. Część z nich uważa, że jest ona naturalnym przejawem globalizacji rynków finansowych i mechanizm tych rynków zapewni potrzebne procesy dostosowawcze. Inna część ekonomistów, nawiqzując do zawodności ryn$k u$, stoi na stanowisku, że niezbędne sa korekty $w$ polityce makroekonomicznej najważniejszych gospodarek. Przykładem takich działań jest proces wielostronnych konsultacji uruchomiony przez Międzynarodowy Fundusz Walutowy. W ramach wielostronnych konsultacji sformułowano właściwy program działań dostosowawczych. Obecnie kluczowe znaczenie ma wdrażanie tego programu przez najważniejsze gospodarki $i$ dostosowanie narodowych priorytetów do priorytetów programu. 